\title{
RECONSTRUCTION OF THE PRECIPITATION IN THE CANARY ISLANDS FOR THE PERIOD | 595-|836
}

\author{
by Ricardo García, Antonio Macias, David Gallego, \\ Emiliano Hernández, luis Gimeno, and Pedro Ribera
}

Records of taxes collected during the seventeenth and eighteenth centuries contribute to understanding of climatic variability of the subtropical North Atlantic region.

T he Canary Islands are a volcanic archipelago located in the subtropical North Atlantic, between $27^{\circ} 37^{\prime}$ and $29^{\circ} 25^{\prime} \mathrm{N}$ latitude and $13^{\circ} 10^{\prime}$ and $18^{\circ} 10^{\prime} \mathrm{W}$ longitude, under the influence of the Azores high. The archipelago's abrupt orography makes the islands much wetter than usual at this latitude, allowing the existence of an old agrarian culture. From the very beginning of the Spanish settlement in the fifteenth century, the Spanish introduced a

affiliations: Garcia, Gallego, and Hernández-Departamento Física de la Tierra II, Facultad de Ciencias Físicas, Universidad Complutense de Madrid, Madrid, Spain; MACIAs—Universidad de La Laguna, Tenerife, Spain; GIMENO-Campus As Lagoas, Universidad de Vigo, Vigo, Spain; RıBera—Universidad Pablo de Olavide, Sevilla, Spain This is an abridged version of the full-length article that is available online (DOI: 10.1 175/BAMS-84-8-García)

CORRESPONDING AUTHOR: Ricardo García Herrera, Dpto. Física de la Tierra II, Facultad de CC Físicas, Universidad Complutense de Madrid, Ciudad Universitaria, Madrid 28040, Spain

E-mail: rgarcia@6000aire.fis.ucm.es

DOI: 10.1 175/BAMS-84-8-1037

In final form 4 March 2003

(20203 American Meteorological Society powerful bureaucratic system managed by the church, aimed at organizing agricultural activities and, most importantly, to keep a record of the production in order to collect taxes. The remaining documents, preserved in the local archives, can provide invaluable information about the climate in the region.

THE DOCUMENTARY SOURCES: ASSESSING THE CLIMATIC SIGNAL. The harvest taxes or tithes, were an annual tribute that affected both agricultural and industrial production. Every producer had to pay $10 \%$ of the total production either in kind (cereals) or in money, after a public auction (rest of the taxed production). The recollection was based on a double-checked procedure specially designed to avoid fraud (Macias 1984a, 1986). For the cereals, a final main account book called libro del pan, preserved in the Gran Canarian's cathedral archives, recorded the collected amount, a direct measure of the total harvest (Macias 1984b). In the Canary Islands the tithes worked homogenously from late sixteenth to mid-nineteenth centuries, when the increasing opposition to this system led to its end in 1837. During this period, the farming methods were essentially the 
same, while the self-consuming nature of the production kept the cereals out of the speculative market.

Two production series per island-wheat and barley-were reconstructed. A general decreasing trend in the production was found across the archipelago as a result of the land-use change, which slowly displaced the cereals to poorer lands as new and more profitable crops were introduced. To eliminate this nonclimatic signal, the raw series were detrended and standardized. The precipitation proxy for the Canary Islands (CPP) was then computed as the averaged and standardized wheat and barley productions for the archipelago (Fig. 1).

Two independent series of dry and wet years (Herrera 1979) were used to assess the precipitation signal in CPP. The linkage between survival and precipitation was the basis of religious events asking for rain during the driest years. Some of them were recorded in documents, making it possible to identify several dry years in the study period. Most of these droughts coincide with CPP minima (gray bars in Fig. 1), with the best example in 1721. On the other hand, during unusually rainy years, the saturation of the terrain could led to the breaking of one of the most important bridges over a ravine near Gran Canaria's capital. Five of such events were located in the study period (dashed lines in Fig. 1), with CPP values above average.

AN NAO PROXY? The North Atlantic Oscillation (NAO) is one of the most important climatic patterns in the Northern Hemisphere (van Loon and Rogers 1978; Barnston and Livezey 1987; Hurrell 1995, among many others). A recent study of the instrumental precipitation in the Canary Islands (García et al. 2001) shows that, during the twentieth century, the NAO has been the main modulator of the Canarian precipitation, with negative correlation between precipitation and the NAO index.

In recent years, great effort had been addressed to extend back in time the NAO index. Jones et al. (1997) have provided the longest instrumental record.
Although the correlation between their index and CPP reaches $-0.74(\mathrm{p}<0.01)$, the short common period (13 yr) makes the comparison with other NAO proxies necessary.

The correlation analysis between CPP and several NAO reconstructions capturing the winter signal resulted in small values (although statistically significant and of the expected sign). Nevertheless, the wavelet analysis (Torrence and Compo 1988, not shown) reveals some of the characteristic NAO bands. CPP exhibits 2-4-yr oscillations also found by Luterbacher et al. (1999), Rodrigo et al. (2001), Cullen et al. (2001), and Cook et al. (2002); a 7-14-yr band is evidenced (also found by Luterbacher et al. 1999; Rodrigo et al. 2001; Cullen et al. 2001; Appenzeller et al. 1998). Long-period oscillations (50-70 yr) can be also found in Luterbacher et al. (1999), Cook et al. (1998), and Proctor et al. (2000), although there is controversy about the significance of this band during historical times (Cook et al. 2002).

CONCLUSIONS. The potential for climate reconstruction in the Spanish archives has been used to reconstruct a precipitation proxy for the Canary Islands for the period 1585-1836. The reconstructed $\mathrm{CPP}$ series adequately reproduces most of the driest and wettest years recorded in the Canarian history.

The spectral analysis suggests a solid CPP response to the NAO. Nevertheless the direct comparison with several NAO proxies reveals discrepancies. Part of the differences could be explained by the absence of a perfect NAO reconstruction as reference. However, the nature of the NAO even during the instrumental period, is still an open question (Wallace 2000; Ambaum et al. 2001). Currently, the NAO is considered a multicenter teleconnection with nonstationary local effects. It seems hard to admit that a single proxy could adequately represent the NAO for a long period. In this sense, CPP can be a valuable piece of the puzzle, since it contributes with information from a region, the subtropical North Atlantic that has been poorly represented in previous reconstructions.

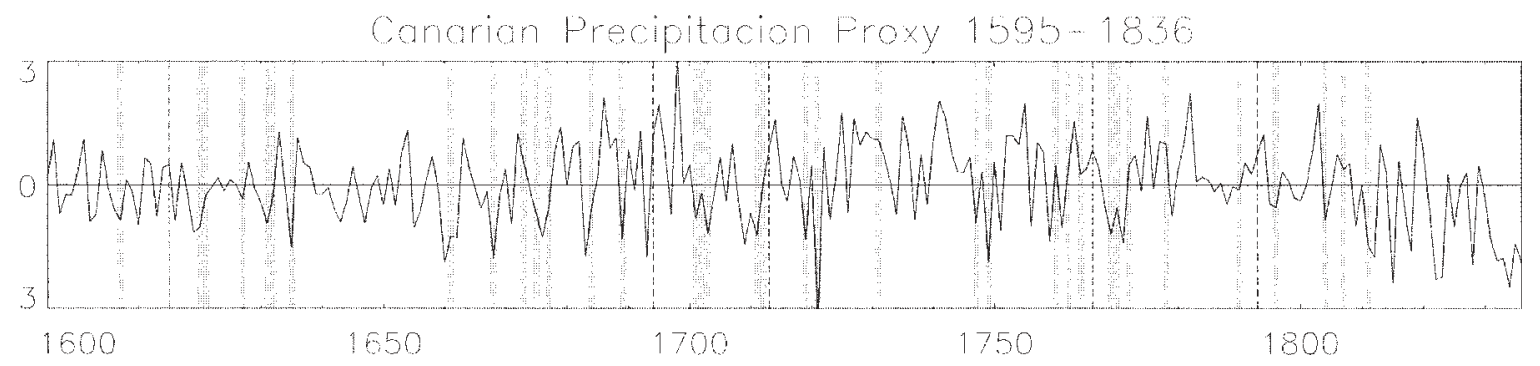

FIG. I. Average crop production record for the Canary Islands. Documented droughts (shaded bars) and wet years (dotted lines) are marked. 
ACKNOWLEDGMENTS. The authors wish to thank C. Appenzeller, E. Cook, J. Luterbacher, C. J. Proctor, and F. S. Rodrigo for providing their proxy NAO reconstructions. This study is supported by the Spanish Comision Interministerial de Ciencia y Tecnologia under Grant CLI98-0649.

\section{REFERENCES}

Ambaum, M. H. P., B. J. Hoskings, and D. B. Stephenson, 2001: Arctic Oscillation or North Atlantic Oscillation? J. Climate, 14, 3495-3507.

Appenzeller, C., T. F. Stocker, and M. Anklin, 1998: North Atlantic oscillation dynamics recorded in Greenland ice cores. Science, 282, 446-449.

Barnston, A. G., and R. E. Livezey, 1987: Classification, seasonality and persistence of low-frequency atmospheric circulation patterns. Mon. Wea. Rev., 115, 1083-1126.

Cook, E. R., R. D. D’Arrigo, and K. R. Briffa, 1998: The North Atlantic Oscillation and its expression in circum-Atlantic tree-ring chronologies from North America and Europe. Holocene, 8, 9-17.

—, - - and M. E. Mann, 2002: A well-verified, multiproxy reconstruction of the winter North Atlantic Oscillation index since A.D. 1400. J. Climate, 15, 1754-1764.

Cullen, H. M., R. D. D'Arrigo, E. R. Cook, and M. E. Mann, 2001: Multiproxy reconstructions of the North Atlantic Oscillation. Paleoceanography, 16, 27-39.

García, R., D. Gallego, E. Hernández, L. Gimeno, and P. Ribera, 2001: Influence of the North Atlantic Oscillation on the Canary Islands precipitation. J. Climate, 14, 3889-3903.

Herrera, P., 1979: Lluvias, sequía y plagas en la historia de Gran Canaria. Aguayro, 107, 10-14.

Hurrell, J., 1995: Decadal trend in the North Atlantic Oscillation-Regional temperatures and precipitation. Science, 269, 676-679.
Jones, P. D., T. Jonsson, and D. Wheeler, 1997: Extension to the North Atlantic Oscillation using early instrumental pressure observations from Gibraltar and South-West Iceland. Int. J. Climatol., 17, 1433-1450.

Luterbacher, J., C. Schmutz, D. Gyalistras, E. Xoplaki, and H. Wanner, 1999: Reconstruction of monthly NAO and EU indices back to AD 1675. Geophys. Res. Lett., 26, 2745-2748.

Macias, A., 1984a: La producción de cereales de Canarias: El ejemplo de trigo (1610-1820). Congreso de Historia Rural, Siglos XV al XIX, Madrid, Spain, Casa de Velazquez, Universidad Complutense, 747767.

— 1984b: Economía y sociedad en Canarias durante el Antiguo Régimen (circa 1500-1850). Ph.D. dissertation, Dept. de Economia, Universidad Nacional de Educación a Distancia, 427 pp.

— 1986: Fuentes para el estudio de la producción agraria en las Islas Canarias: El diezmo en la Diocesis Canariense. Anuario de Estudios Atlanticos, 32, 269354.

Proctor, C. J., A. Baker, W. L. Barnes, and M. A. Gilmour, 2000: A thousand year speleothem proxy record of North Atlantic climate from Scotland. Climate Dyn., 16, 815-820.

Rodrigo, F. S., D. Pozo-Vazquez, M. J. Estenban-Para, and Y. Castro-Diez, 2001: A reconstruction of the winter North Atlantic Oscillation Index back to AD 1501 using documentary data in southern Spain. J. Geophys. Res., 106, 14 805-14 818.

Torrence, C., and G. P. Compo, 1998: A practical guide to wavelet analysis. Bull. Amer. Meteor. Soc., 79, 62-78.

van Loon, H., and J. Rogers, 1978: The seesaw in winter temperature between Greenland and northern Europe. Part I: General description. Mon. Wea. Rev., 106, 296-310.

Wallace, J. M., 2000: North Atlantic Oscillation/Northern Hemisphere annular mode, 2000: One phenomenon, two paradigms. Quart. J. Roy. Meteor. Soc., 126, 791-805. 